\title{
HUBUNGAN LAMA BEDREST TERHADAP FUNGSI KOGNITIF PADA PASIEN LANJUT USIA
}

\author{
Eko Prabowo ${ }^{1)}$, Agustiyawan ${ }^{2)}$ \\ Prodi D-III Fisioterapi, Fakultas Ilmu Kesehatan, UPN "Veteran" Jakarta \\ Email : eko.prabowo@upnvj.ac.id
}

\begin{abstract}
Background : in static people, in 2017 for 23,66 million people for older people. In country in have structure old if have older people more 7 percent. The purpose of this study was to examine correlation bed rest for kognitif function in older people. Method; this study is crocc sectional in design for anayze correlation bed rest for functional cognitive for older people. This study conductes in PSTW Budi Mulia 4 Jakarta. Samples that frr he inclusion and exclusion criteria. Result : The smaples obtained were 18 respondets. Univariate an bivariate analysis test were conducted. Data is not normally distributed. The result spearmen test for nilai $p=0,000$ is have correlation bed rest for cognitive function in older people
\end{abstract}

Key words : Bed Rest, Kognitif Function, Older people

\begin{abstract}
ABSTRAK
Pendahuluan : Berdasarkan data proyeksi penduduk, diperkirakan tahun (2017) terdapat 23,66 juta jiwa penduduk lansia di Indonesia (9,03\%). Suatu negara dikatakan berstruktur tua jika mempunyai populasi lansia di atas tujuh persen. Tujuan penelitian ini adalah untuk mengkaji hubungan bed rest terhadap fungsi kognitif lansia. Metode : Penelitian ini adalah penelitian menggunakan metode penelitian cross sectional yang dirancangan untunk mengetahui hubungan bed rest terhadap fungsi kognitif pada lanjut usia. Penelitian ini dilakukakn di PSTW Budi Mulia 4 Jakarta. Sampel yang digunakan sesuai kriteria inklusi dan ekslusi. Hasil : sampel yang diperoleh berjumlah 18 orang. Dilakukan uji analisis univariat dan bivariat. Data berdistribusi tidak normal. Hasil uji spearmen dengan nilai $p=0,000$ berarti $p<0,005$ maka ada hubungan bed rest terhadap fungsi kogniti lansia. Kesimpulan : Penelitian ini disimpulkan bahwa ada hubungan Bed Rest terhadap fungsi kognitif lansia.
\end{abstract}

Kata kunci: Bedrest, Fungsi Kognitif, Lanjut Usia. 


\section{Penduhuluan}

Peningkatan angka usia harapan hidup tidak selalu disertai dengan peningkatan kualitas hidup pada lansia. Kualitas hidup merepresentasikan respons seseorang terhadap faktor fisik (objektif) dan mental (subjektif) yang berkontribusi ke dalam kehidupannya, termasuk di dalamnya kualitas kekuatan fisik, hubungan dengan orang-orang di sekitarnya baik keluarga maupun temannya, suasana lingkungan, status finansial, dan status emosional. Lansia mengalami penurunan stamina fisik dan ketajaman mental semakin usia bertambah, serta juga bisa mengalami gangguan emosional, yang diakibatkan oleh kesepian, terganggunya aktivitas seksual, kelainan metabolik kronik, dan kanker ${ }^{(1)}$.

Berdasarkan data proyeksi penduduk, diperkirakan tahun (2017) terdapat 23,66 juta jiwa penduduk lansia di Indonesia $(9,03 \%)$. Suatu negara dikatakan berstruktur tua jika mempunyai populasi lansia di atas tujuh persen (soeseno). Belum seluruh provinsi di Indonesia berstruktur tua. Ada 19 provinsi $(55,88 \%)$ provinsi Indonesia yang memiliki struktur penduduk tua. Tiga provinsi dengan persentase lansia terbesar adalah DI Yogyakarta $(13,81 \%)$, Jawa Tengah (12,59\%). Sementara itu, tiga provinsi dengan nilai terkecil adalah Papua $(3,20 \%)$, Papua Barat $(4,33 \%)$ dan Kepulauan Riau (4,35\%). Sedangkan persentase penduduk lansia pada DKI Jakarta adalah (7,19\%). Angka harapan hidup perempuan lebih tinggi dari pada lakilaki, hal ini terlihat dengan keberadaan penduduk lansia wanita lebih banyak dari pada penduduk lansia laki-lak ${ }^{(2)}$.

Proporsi populasi lanjut usia (lansia) di dunia meningkat dari 9\% pada tahun 1950 menjadi 12\% pada tahun 2013. Peningkatan ini akan terus terjadi pada empat dekade mendatang hingga mencapai $21 \%$ pada tahun 2050.1 World Health Organization (WHO) memprediksikan pada tahun 2050 setidaknya terdapat 2 milyar orang berusia 65 tahun ke atas dibandingkan dengan 600 juta pada saat ini ${ }^{(3)}$.

Penurunan fungsi kognitif terjadi pada hampir semua lansia dan prevalensinya meningkat seiring bertambahnya usia. Perubahan kognitif seseorang dikarenakan perubahan biologis yang dialaminya dan umumnya berhubungan dengan proses penuaan. Gangguan satu atau lebih fungsi tersebut dapat menyebabkan gangguan fungsi sosial, pekerjaan, dan aktivitas harian. Pengkajian fungsi mental kognitif merupakan hal yang menyokong dalam mengevaluasi kesehatan lanjut usia, banyak bukti menunjukkan bahwa gangguan mental kognitif seringkali tidak dikenali profesional kesehatan karena sering tidak dilakukan pengujian status mental secara rutin. Diperkirakan $30 \%$ sampai $80 \%$ lanjut usia yang mengalami demensia tidak terdiagnosis oleh dokter, melainkan teridentifikasi melalui Mini Mental State Examination (MMSE) ${ }^{(4)}$.

Imobilisasi adalah ketidakmampuan untuk bergerak bebas yang disebabkan oleh kondisi di mana gerakan tergganggu atau dibatasi secara terapeutik yang bisa berhubungan langsung dengan faktor internal seperti penyakit kronis atau status kesehatan. Contohnya penyakit gizi buruk, paralisis, diabetes mellitus, gangguan kardiovaskuler, lansia, inkontinensia, anemia, berat badan. Sehingga pasien harus beristirahat total atau biasa disebut dengan bedrest total ${ }^{(5)}$.

\section{Metode}

Penelitian ini merupakan penelitian bersama dan cross sectional study. Penelitian ini akan dilakukan bersama untuk jenis kasus dan sample yang sama. Oleh karena itu, jumlah penentuan besar sampel dalam penelitian ini merupakan gabungan hasil perhitungan dari semua kelompok yang tergabung dalam penelitian Bersama. Subjek penelitian in adalah warga binaan sosial PSTW Budi Mulia 4 Jakarta.

Teknik Pengumpulan data : 1) memilih calon responden sesuai dengan kriteria inklusi dan eksklusi menggunakan Teknik purposive sampling yaitu Warga Binaan Sosial PSTW Budi Mulia 4 Jakarta, 2) Mendatangi calon responden, menjelaskan maksud dan tujuan penelitian. Peneliti membawa surat permohonan serta kuesioner dan lembar persetujuan untuk menjadi responden, 3) Peneliti menjelaskan tahapan penelitian setelah calon responden bersedia menjadi responden, 4) Responden menandatangi lembar persetejuan dihadapan peneliti, 5) Peneliti melakukan pemeriksaan 
Bed Rest dan MMSE kepada responden dari riawayat penakit, vital sign

Analisis data menggunakan analisis univariat dan bivariat, univariat terdiri factor individu yaitu umur, jenis kelamin,

Analisis bivariat dilakukan untuk menguji Hubungan Bed Rest terhadap Pada Orang Lanjut Usia. Uji yang digunakan adah uji spearmen

\section{Hasil dan Pembahasan}

Deskripsi data sampel dilakukan dengan analisa univariat untuk mengetahui frekuensi jenis kelamin dan Kelompok Umur

Tabel. Distribusi Karakteristik Subyek berdasarkan jenis kelamin, kelompok umur pada kelompok intervensi

\begin{tabular}{lcc}
\hline Karakterik Responden & $\mathrm{N}$ & $\begin{array}{c}\text { Prosenta } \\
\text { se (\%) }\end{array}$ \\
\hline $\begin{array}{c}\text { Kelompok } \\
\text { Jenis } \\
\text { Kelamin } \\
\text { Laki-laki }\end{array}$ & 2 & $12,5 \%$ \\
Perempuan & 16 & $87,5 \%$ \\
Umur & & \\
$60-70$ & 16 & $87,5 \%$ \\
$71-80$ & 2 & $12,5 \%$ \\
\hline
\end{tabular}

Berdasarkan data table diatas responden terbanyak berjenis perempuan berjumlah 16 orang sedangkan responden laki - laki berjumlah 2 orang.

3.1 Analisis Hubungan Bed Rest terhadap Fungsi Kognitif Lansia

\section{a. Uji Normalitas}

Hasil dari analisis bivariat Hubungan Bed Rest terhadap Fungsi Kognitif Lansia . Sebelum dilakukan uji bivariat maka terlebih dulu dilakukan uji Normalitas. Uji normalitas akan dilakukan dengan Kolmogorov-Smirnov. Uji ini dilakukan unuk memenuhi ketentuan pengujian uji statistik. Uji statistik tersebut adalah uji statitik paramerik untuk yang berdistribusi normal dan non paramerik untuk yang berdistribusi tidak normal

Tabel Uji Normalitas lama Bed Rest dan MMSE

\begin{tabular}{ll}
\hline Kategori & Nilai Uji \\
\hline Lama Bed Rest & 0,040 \\
MMSE & 0,008 \\
\hline
\end{tabular}

\section{b. Uji Bivariat}

Hasil Uji perbedaan menggunakan Spearmen : Hasil $\mathrm{p}<0,05$ maka hipotesis diterima

Uji Spearmen

\begin{tabular}{lll} 
Kategori & $\mathrm{P}$ \\
\hline $\begin{array}{l}\text { Bed Rest \& } \\
\text { MMSE }\end{array}$ & 0,000 \\
\hline
\end{tabular}

Berdasarkan tabel diatas diperoleh $\mathrm{p}<0,005$ maka ada ada hubungan signifikan anatara lama bed rest dan MMSE

\section{Kesimpulan}

Berdasarkan hasil penelitian yang telah dilakukan dapat disimpulkan bahwa :

Adanya Hubungan Bed Rest terhadap Fungsi Kognitif pada Lansia

\section{Ucapan Terima kasih}

Terima Kasih kepada Universitas Pembangunan Nasional "Veteran" Jakarta yang telah memberikan dana pada kegiatan penelitian

\section{REFERENSI}

[1,3]. Stein, L. K., Wiramihardja, S., \& Kulsum, I. D. 2018. Muscle Mass and Quality of Life of Elderly People in Panti Tresna Werdha in Bandung Faculty of Medicine Padjadjaran University-2(1), 637-645.

[2]. Kementrian Kesehatan RI. Pisat Data dan Informasi (Analisis Lansia). Jakarta. 2017

[4]. Nugroho W. Keperawatan gerontik \& geriatrik Ed.3. Jakarta: EGC; 2008. Jayanti, R. R., Imanto, M., A, D. I., Kedokteran, F., Lampung, U., Ilmu, B.,

[5]. Arief, S., Kriatyawati, S. P., \& Sarwanto, D. P. (2016). Perbedaan Efektivitas Posisi Miring 30 Derajat Dan 90 Derajat Dalam Menurunkan Risiko Dekubitus Pada Pasien Bedrest Total Di RSUD Salatiga 1-12. 